\title{
DOMINANT FEATURES OF THE ART WORLD OF ALEXEY SALNIKOV
}

\author{
Elvina Abdulkhakovna Azimova
}

Lecturer, Department of Russian Language And The Methods Of Teaching It, Jizzakh State Pedagogical Institute Named After A. Qadiri, Uzbekistan

\section{ABSTRACT}

This article examines the dominant features of the artistic world of Alexey Salnikov. A comparative analysis of the author's stories and a comparative analysis of the story of Alexei Salnikov "One, two, three, four" and the story of Lyudmila Petrushevskaya "New Robinsons" are carried out.

KEYWORDS: - Theme, narration, style, heroes, motive, stylistic paths, dialogue, landscape.

\section{INTRODUCTION}

Alexey Salnikov is a Russian poet and prose writer, winner of the National Bestseller Prize. The works of a contemporary writer are welcomed by readers. In the works of many Russian writers, the theme of the Motherland sounds like a red line through their work. Love for the Motherland, for the people is a source of inspiration for many writers. Homeland evokes bright feelings in a person. And it is difficult to name a writer who would not devote to his homeland the lines that come from the heart, the most sincere, the most reverent. And Alexey Salnikov is no exception. The story "One-two-threefour" was published in the journal "Vestnik Evropy" in 2020, a work reflecting the theme of the Motherland.

The main characters are father Sasha, mother (the author does not name) and son Oleg. The family moved from Estonia to the Urals. A dialogue took place between the father and the mother, where the mother expresses her discontent with the head of the family about the people living in the area where they have recently moved, the father, reassuring him, explained that this is a working area: “I don't know," my mother held out. - How can you get accustomed here among this nasty weather, oats and rudeness ..." [12].

A month later, Oleg went to first grade, and his mother got a job in the same school as a teacher of Russian language and literature, and she had no time to look for differences between Estonia and the Urals. The passion for work was so strong that Sasha already started a conversation about his son, reporting on the late return of his son home, and the proposal to give his son to be raised by his grandmother Vera Pavlovna, to which he heard a negative answer. And to the offer to talk to her son after the prolongation, the mother responded disapprovingly, explaining that she was ashamed to run to her son, a future man, and "wipe the snot" in 
CURRENT RESEARCH JOURNAL OF PHILOLOGICAL SCIENCES 2(9): 66-72,

September 2021

DOI: https://doi.org/10.37547/philological-crjps-02-09-14

ISSN 2767-3758

(C2021 Master Journals

Crossref doi

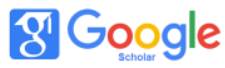

Accepted25 $5^{\text {th }}$ September, 2021 \& Published $30^{\text {th }}$ September, 2021

front of classmates. And yet there is a plus in the fact that the local people are vigilant.

The fact is that, before Oleg went to school, he was constantly looked after. If Oleg did not go to the kindergarten, then he spent time with his grandmother, who took him with her to visit her friends. The boy could only find entertainment for himself: looking at magazines, leafing through books without pictures, walking around someone else's house and looking into all corners. And the hero at a conscious age realized how clean the houses of these old women were, which made him not stand out.

After the move, Oleg was timid to go out into the street. It seemed to the boy something unusual to go to the store for bread, but after a few days it passed. As soon as the hero walked around the yard, and now he is already playing with other children, exploring the lathe shop, coal boiler house, construction site and watching the demolition of the old house.

In just a month, Oleg managed to survive more than in his entire life. Twice his life nearly ended. He was drowning and nearly hit by a car. It seemed that he had completely taken root, but no, Oleg lacked another life, with different trees, houses and people. The nature aroused nostalgia in the boy: chestnuts, an oak forest, a river.

Oleg wanted to be somehow different from other children, it seemed to him that the duality of impressions made him somehow special, unlike the other children.

He continued to look for something familiar with Estonia in each of the houses. The wooden twostory house of my best friend, a house in the private sector, everything resembled the Motherland.

Ten months later, my parents decided to visit my grandmother. For Oleg, these months passed like several years, and the distance, letters, parcels from his grandmother alienated his former life, however, approaching his familiar and familiar places, he ran ahead of his parents.

After some time, Oleg completely got used to it, the remaining two weeks in Estonia did not let go of him anywhere. They took him to his relatives, to meetings with friends of his father, mother, to the dacha to his acquaintances, where there were no children at all, and then he got bored of the Urals. Longing for nature: porcini mushrooms, strawberries, flowers, pebbles that look like malachite.

But, upon returning home, Estonia became "watercolor" in Oleg's head. There were several more trips, Estonia became abroad. A sense of duality did not leave him.

The story shows the intertwining of the life of the protagonist Oleg and the author. A. Salnikov comes from Estonia, the city of Tartu and currently lives in the Urals in Yekaterinburg.

The type of storytelling is event-driven storytelling. Event narration gives an idea of the sequence of actions and events, changes in the life of a person or group of persons, society, state, and the like. Event narration is based on sequential sentences denoting events and actions. In the event narration, the author draws the readers' attention to the components of the world of events: events, actions, decisions.

"The point was that all the time, literally until the first days at school, someone was sitting with Oleg, someone constantly surrounded him with their attention. Before moving to the Urals, Oleg did not have the opportunity to just go outside and go for a walk wherever he liked. If Oleg was not in kindergarten, his grandmother dragged him around 
CURRENT RESEARCH JOURNAL OF PHILOLOGICAL SCIENCES 2(9): 66-72,

September 2021

DOI: https://doi.org/10.37547/philological-crjps-02-09-14

ISSN 2767-3758

(C)2021 Master Journals

Crossref doi

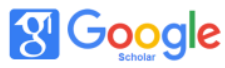

Accepted25 $5^{\text {th }}$ September, 2021 \& Published 30 ${ }^{\text {th }}$ September, 2021

to her friends, which, of course, was not a paddle at all "[12].

In this example, sentences with predicates in the form of past tense verbs convey a sequence of events in a short period of time. There is a logical connection between the sentences. The author drew attention to the reporting of successive events.

A. Salnikov's style is simple and natural. These qualities must be possessed by a writer. In the writer's works you will not find any extravagant heroes and exceptional events, heroes with their experiences and states are common, natural.

The main characters of A. Salnikov are ordinary people with their own desires and needs. Individuals with a similar social status, simple workers who took place in life: "And then there was such a year when married couples, consisting of a bricklayer, which is Yutakuronov, .." (Communicate! Live!) [13]. The heroes have value orientations, a certain outlook on the world: homesickness or vice versa, an old house left over from grandparents has lost everything of value that was in it, there is also a financial interest: "He remembered that life could be different, they can other trees grow outside, other houses can stand, and people can be different ..."[12].

The unifying element for the characters of the writer is the motive of the house. The image of the house is interpreted in different ways. In the stories compared, there is a desire to return to the house, sell it, or purchase it.

The word "house" evokes in any representative of Russian culture not only an individually-sensual image of his own home, but also refers to important semantic meanings: "So, house - 1)" his "space, a closed space (fenced off from the outside world); 2) the place of life of a person, his homeland; 3) a protected refuge of a person, opposed to the rest of the "alien" and usually hostile world; 4) the center of the family hearth, a place that unites relatives or close people; 5) the focus of coziness, warmth, comfort, beauty; 6) a place to which a person is emotionally attached "[1, p. 107].

A family home is a complex, versatile concept that includes a family where a child is born and grows up, an atmosphere of a home, including family traditions, a place where close relatives live, friends nearby, trees and plants close to the soul grow. With the passage of time, the concept of "home" expands, the street, city, country become relatives. This is the main character of the story "One, two, three, four" - Oleg. From a young age to adulthood, he was surrounded by the concept of "home" from family and trees to the city and country. For the main character of the story "Communicate! Live! " home is about improving living conditions. The couple became cramped in the old house, they decided to buy a large-sized apartment on credit: "They themselves did not believe that they could pay off the mortgage by earning money with their hands, but it was necessary to increase the living space from one-room to two-room, because they began to appear in their life together is a kind of tension." [13].

The author has a positive attitude towards the main character in the story "One, two, three, four". Despite the change of place of residence, Oleg, thanks to his curiosity, sought adventure, found comrades and completely settled in a foreign country: " I got accustomed completely, "Mom and Dad talked about Oleg and sighed equally" [12]. A. Salnikov notes in the hero a desire to be different from others, manifested through longing for the Motherland: "Not being able to think of how he differs from other children in the same school uniform, in the same coats, in the same coats, in the 
CURRENT RESEARCH JOURNAL OF PHILOLOGICAL SCIENCES 2(9): 66-72,

September 2021

DOI: https://doi.org/10.37547/philological-crjps-02-09-14

ISSN 2767-3758

(C2021 Master Journals

Crossref do

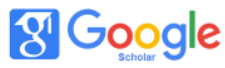

Accepted25 $5^{\text {th }}$ September, 2021 \& Published 30 ${ }^{\text {th }}$ September, 2021

same shoes, with the same Octobrist stars, and already wanted to somehow distinguish himself from others, Oleg came up with this duality of impressions makes him somehow special ... That dreams with other people's landscapes and strange streets are dreamed of by him alone."[12].

The author's work is distinguished by the use of stylistic tropes. The abundance of comparisons enhances the shades of the meaning of the work: "Puffing out my cheeks, as if I were blowing on hot tea"; "He... like a mole from under the ground was looking out of the basement windows" [12].

The author, with the help of epithets, attracts the attention of readers, enhancing the expressiveness of the images of the described objects and phenomena: "Lulled by dinner, nasty weather," [12].

Impersonation enhances thoughts and feelings, creates expressive and imaginative paintings: "The floors have managed to be powdered with city dust that entered through the anti-camarine nets of windows and balconies" [12].

The inversion emphasizes the role of the emphasized word: "... in a playful and at the same time sad jump from note to note of the melody ..." [12].

In the analyzed story, the type of dialogue is a conversation, which is a frequent occurrence in the works of A. Salnikov:

- This is some kind of savagery - said my mother, ...

Is a toilet for three families better? - "Sasha" objected calmly .... [12].

In the story under study, the characterological function of the dialogue is noted, which tests the author's heroes, which is noted as an important feature of the writer's stylistics. Dialogue acts as a way of modeling a "speech mask", reflects the originality of the speech behavior of A. Salnikov's characters. In the author's stories, the dialogue performs an evaluative function, which allows one to present several evaluative positions.

The evaluative position is the perception and evaluation by the author and the actors of the characters, situations, and actions portrayed.

Peculiarities of perception of the world, aesthetic and evaluative orientations of A. Salnikov's heroes are found in the dialogues of stories.

Dialogue as a form of communication is a dynamic structure. The originality of a literary text as a communicatively directed verbal work with aesthetic value lies in its anthropocentricity, cultural significance and the ability to embody in a figurative form a special artistic picture of the world modeled by the author. In this regard, artistic dialogue appears as a product of one of the most difficult types of communication - artistic and literary, the subjects of which, in addition to the author and the reader, are characters [2, p. 150151].

At the beginning of the analyzed story, an everyday scene is carried out, the dialogue plays an important role, from which the text begins, representing the main characters:

- This is some kind of savagery - said my mother, ...

- Is it better to have a toilet for three families? "Sasha" objected calmly ...

- But there were no shouts in the queue, there was no "Maaaash!" [12].

In the dialogue of Sasha, the head of the family and Oleg's mother, the mother takes a response position, which is a violation of the rules of speech behavior, but aesthetically justified by the creation of a certain "spectacle" of the communication situation.

In the dialogue of the story, there is a polyphonism 
CURRENT RESEARCH JOURNAL OF PHILOLOGICAL SCIENCES 2(9): 66-72,

September 2021

DOI: https://doi.org/10.37547/philological-crjps-02-09-14

ISSN 2767-3758

(C)2021 Master Journals

Crossref doi

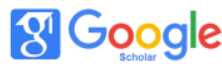

Accepted25 $5^{\text {th }}$ September, 2021 \& Published $30^{\text {th }}$ September, 2021

of the characters' experiences: a feeling of anxiety, the fussiness of the mother, the equanimity and calmness of the dad. The writer managed to subtly, through the conversations of the heroes, emphasize the incompatibility of the heroes of the work.

Checking the characters of A. Salnikov's characters is carried out not only through the author's narration, but also through dialogue, therefore, the characterological function is of particular importance, which is noted as an important feature of the writer's prose stylistics.

In the stories of A. Salnikov, the dialogue performs an evaluative function, as it makes it possible to present several evaluative positions. The evaluative position (point of view) is the perception and evaluation of the depicted (heroes, situations, actions) by the author and the actors [7, p. 386]:

- How are you? - asked the foreman, hanging over the lying worker. - Nothing hurts?

- It seems normal, - answered Yutakuronov.

- He's in shock! - someone from the audience shouted, and everyone nodded gloomily [13].

A literary landscape can be interpreted as a visual or multisensory (with the mandatory presence of a visual component) image of a pristine or open natural space containing traces of human presence, which is created with the help of linguistic means, carrying an informational and emotional-aesthetic load $[6 ; 7]$.

Landscapes are classified on a local basis, that is, by the geographical location of the depicted natural objects or the general nature of the area [8, p. thirty]. There are such landscapes as steppe, forest, sea (marina), mountainous, urban / urban, rural and so on $[8, \mathrm{p}$. thirty]. According to the seasonal criterion, landscapes can be easily divided into spring, summer, autumn and winter. [8, p. 30].

Boeva N.V., Gosteva T.F. distinguish the classification of literary landscapes, based on the analysis of the volume and local location of the landscape in the text. The following types of landscapes are distinguished: contour, or dashed (a landscape is a short description, to which the author refers only once); dispersive hatching (several hatched landscape descriptions are distributed throughout the work); compactdescriptive (the landscape is represented by one volumetric text unit); dispersive-descriptive (detailed capacious landscape descriptions are scattered throughout the narrative) [9, p. 190-194; 10].

In the stories of A. Salnikov, the landscape is classified according to a local criterion, a forest, urban description of the landscape is noted:

"First of all, there were not enough chestnuts ... and he sees thorny, but at the same time, cozy-looking small green balls among the leaves on the ground whole and split into two halves. Oak trees were also missing. How cozy the forest was ... "[12].

In the work of the author, there is a seasonal criterion for the landscape:

"Ivanov again looked into the sky, where the sun had been peeking out between two motionless clouds for more than forty minutes and everything could not stop peeping out. Wormwood and nettles, like zombies, were pulling their thick, bright, green paws through the gaps in the slatted fence ... A ground beetle ran under Ivanov's feet. An amazing thing: Ivanov was literally thrilled by the heat, his daughter too, and in the beetle, which did not contain a teaspoon of water and had to roast at lightning speed in the sun, there was more life than both of them "[14].

According to the seasonal criterion, the considered landscape describes the summer season.

In A. Salnikov's prose, the following types of 
CURRENT RESEARCH JOURNAL OF PHILOLOGICAL SCIENCES 2(9): 66-72,

September 2021

DOI: https://doi.org/10.37547/philological-crjps-02-09-14

ISSN 2767-3758

(C2021 Master Journals

Crossref do

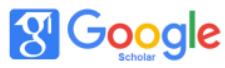

Accepted25 $5^{\text {th }}$ September, 2021 \& Published 30 ${ }^{\text {th }}$ September, 2021

landscapes are distinguished: contour, dashed, dispersive-dashed.

In the article we used a comparative analysis of A. Salnikov's stories "One, two, three, four" and L. Petrushevskaya's novel "New Robinsons" in order to identify the dominant features of A. Salnikov's artistic world. The works of the writers are distinguished by their artistic originality, while the genre of works brings them together - short stories. The main characters of the stories are completely different people. Oleg, the protagonist of the story "One, two, three, four" is distinguished by longing for the motherland, the opposite is the father, the head of the family in the story "New Robinsons", who left the city with his family and moved to the village, ran away from civilization, self-isolated from the reigning totalitarian regime.

In the analyzed works, the authors have different attitudes to the literary landscape in the work. In the works of L. Petrushevskaya, there is a lack of description of the landscape. In the story of A. Salnikov, the landscape performs a symbolic function and reveals the character of the hero through the description of nature.

The scarcity of metaphors, a distinct portrait, and formal compositional completeness are a feature of writers.

A. Salnikov uses a dialogue that conveys the diversity of life, defining the character of the protagonist. L. Petrushevskaya in the story "New Robinsons" does not use dialogue as a form of speech.

Thus, A. Salnikov's writing style is simple and natural, the main characters are ordinary people with their desires and needs. Stylistic tropes, dialogical speech are the author's distinctive features. The landscape is an integral feature of the writer's work.

\section{ReFERENCES}

1. Morarash M.M. Semantic-cognitive study of the concept of DOM in the novel by V.V. Nabokov's "Mashenka" // Scientific Dialogue. Yekaterinburg, 2017. -№ 8. - S. 104-115.

2. Mikhailov N. N. Theory of artistic text. M : Academa, 2006.220 p.

3. Gatinskaya NV Interaction of genuine and playful principles in language and artistic worlds // Logical analysis of language. Conceptual game fields. M .: Indrik, 2006.S. 255261.

4. Durov A. A. From ritual to literature // Text: carpet patterns. Stavropol: Publishing house of the Stavropol University, 1999.S. 134-143.

5. Introduction to Literary Studies / Ed. L. V. Chernetz. M .: Higher school, 2006.680 p.

6. Voronin, RA Landscape as an object of philological research // Actual problems of modern science. - 2015. - S. 165-167.

7. Voronin, RA Arctic landscape in the work of Jack London "White Fang" // Actual problems of modern science. - 2016. - S. 5-9.

8. Zelentsova, S. V. Functions of the landscape in small prose I. A. Bunin: on the material of the works of 1892-1916: dis. on the job. scientist. step. Cand. philol. sciences. - Oryol, 2013 .-- 192 p.

9. Boeva, NB Features of the syntactic organization of landscape contexts in modern English and American stories // Scientific Thought of the Caucasus. - 2004. - No. 12. - P. 190-194.

10. Gosteva, TF Linguistic features and textforming potential of landscape descriptions in American prose of the XIX-XXI centuries: dis. on the job. scientist. step. Cand. philol. sciences. Barnaul, 2007 .-- 237 p.

11. 11.Wilson R. Rawdon. In Palamedes'shadow. Boston, 1990.

12. 12.Electronic

resource: 
CURRENT RESEARCH JOURNAL OF PHILOLOGICAL SCIENCES 2(9): 66-72,

September 2021

DOI: https://doi.org/10.37547/philological-crjps-02-09-14

ISSN 2767-3758

(C)2021 Master Journals

\section{Crossref dof 81 Google}

Accepted25th September, 2021 \& Published 30 ${ }^{\text {th }}$ September, 2021

https://www.livelib.ru/author/429832/top-

aleksej-salnikov

13. 13.Electronic resource: https://snob.ru/entry/201777/

14. 14.Electronic resource: https://meduza.io/feature/2020/09/25/nezhn yh-vospominaniy-ne-bolshe-chem-nachaynuyu-lozhku 